\title{
Profiling Crime in Pakistan: An Aggregated and Disaggregated Socioeconomic Analysis
}

\author{
Ayesha Anwar ${ }^{1}$, Sofia Anwar ${ }^{2}$ and Shabib Haider Syed ${ }^{3}$
}

\begin{abstract}
Crime is more than just a sociological and psychological phenomenon. The economic effects of any criminal activity are intriguing and vice versa. This paper attempts to profile crime scenario in Pakistan in the socio-economic context at aggregated and disaggregated level. Three crime supply models have been constructed using formal econometric techniques i.e., aggregated crime, crime against person and crime against property. These models depict the various socioeconomic variables effecting different crimes. The paper also captures the deterrence effect but on a very limited scale using police strength as proxy. The paper has drawn many conclusions indicating effects of social and economic injustices making people choose illegal activities over lawful ways of earnings and the role of government to intervene and promote socio-economic equity. Government should introduce effective social security programs to create more jobs and to minimize income inequalities. Policing and effective justice system is key to control crime.
\end{abstract}

Keywords: Crime, Deterrence, Socioeconomic, Pakistan, Income Inequality.

JEL Classification: K42

1. Introduction

Criminology was more considered the province of sociology and psychology until Gary Becker provide economic treatments to the topics of crime and punishment (Forst, 1993). However as per the historical perspective, the notion that economists are encroaching field of criminology is questionable because Jeremy Bentham ${ }^{4}$ who assigned benefit/ cost markings to criminal activities was also one of the founders of utility theory (Fisher, 2015).

Criminal activity can be discerned from two perspectives. The first, is the microeconomic perspective where a person decides to choose between legitimate

\footnotetext{
${ }^{1}$ PhD Scholar, Department of Economics, GC University, Faisalabad, Pakistan.

${ }^{2}$ Department of Economics, GC University, Faisalabad, Pakistan.

${ }^{3}$ Department of Economics, Minhaj University, Lahore, Pakistan.

Corresponding author's Email: ayeshaanwar@fccollege.edu.pk

${ }^{4}$ Jeremy Bentham (1748 - 1832) was an English Philosopher, Jurist, social reformer regarded as founder of modern utilitarianism. He contributed significantly to the development of constitutional codes of the criminal justice system of the Great Britain.
} 
work and illegal activities. Further, the individual allocates time for each activity. On the other hand, there is Jack Katz' approach where the criminal acts are done for sensual thrill and out of curiosity (Hellman and Alper, 2000). Gery Becker (Becker, 1968) and Isaac Ehrlich (Ehrlich, 1973a) has provided a proper framework for economic modelling of criminal behaviour. Economists has brought into light a strong supposition that criminal behaviour can be modelled using the traditional economic theory of choice, risky decision-making, demand for leisure or equivalent supply for labor, firm behavior, and even market structure (Mafias ) and performance (Hellman and Alper, 2000; List and Uhlig, 2017).

The second perspective is the overall health of the economy, or in simple words the macroeconomic conditions also influence the criminal activity in a country. Improved economic conditions can increase the value of time, as the availability of legal opportunities increase, people are less likely to chose illicit activities (Hellman and Alper, 2000). Improved economy's health mean increases in GDP and reduction in rate of unemployment, Income level of masses goes up which leads to more production of good and services and consequently more opportunities in legal sector (Goulas and Zervoyianni, 2013).

Crime creates negative externality so proper social and economic measures are required to tackle this. Economist working in the field of crime are working into two dimensions; one to explore the economic and social determinants of crime and second to design and provide effective policy measures (deterrence, punishment, prison strength and elasticities). This paper aims to look at the socio-economic determinants of crime with respect to Pakistan, focusing on Crime against person and prime against property. While profiling the socio-economic factors effecting of crime, one needs to see how crime interacts with different and heterogeneous fields? Crime rate has increased at an alarming rate in Pakistan, leaving the justice system choked with thousands of pending cases (Syed and Ahmed, 2013). Crime is precisely related to poverty (Carr-Hill and Stern, 1983; Pratt and Cullen, 2005) Social exclusion and deprivation (Higgins, Gabbidon, and Martin, 2010), unemployment (Chiricos, 1987; Freeman, 1994; Imrohoroglu, Merlo, and Rupert, 2001) wages and income inequality (Burdett, Lagos, and Wright, 2003; Chiu and Madden, 1998; Ehrlich, 1973b; Fleisher, 1966) and level of education (Lochner, 1999; Lochner and Moretti, 2001; Wilson and Herrnstein, 1998).

\section{Review of Literature}

Since Becker's (1968) seminal paper, economists have explored different dimensions in the field of economics of crime and punishment. Recently, studies are available that explore determinants and consequences of crime both at micro 
and macro level. The very first economic perspective on crime came from Fleisher (1966) from public policy point of view where he focused of labor market functioning. He developed an understanding of how population distribution and wage distribution effect the choices of people towards legal and illegal means of earnings. But it was Gery Becker's (1968) economic analysis of criminal behaviour that enabled researchers to analyse a society's choice mechanism of crime and crime control policies. He developed a simple theoretical economic model of benefit-cost analysis to explain this phenomenon. In fact, Becker referred Crime as an industry and an economic activity. Ehrlich (1973) extended the work of Becker and studied the relationship of income level and its distribution effect crime rate and propensity to indulge into criminal activity. Fleisher (1966) and Ehrlich (1973) both considered as complementary indicator, as it defines the availability of legal income opportunities in labour market (Grogger and Freeman, 1994). Imrohoroglu et al. (2000) follow the lead and discovered that low-income levels are more related to crime rate than unemployment. The high rates of unemployment and low levels of income leads towards poverty and adverse standards of living. Poverty and not being able to benefit justly from the legal activities can offend an individual and persuade him to choose earing means otherwise. Syed and Ahmed (2013) drawn the similar results for Pakistan. They emphasized that resources must divert from large criminal justice system to the provision of social justice. Poverty, income inequality and unemployment are not only the three major economic problems but also the social evils that are putting people in such a deprived position that they are forced to choose illicit activities to win bread and butter for themselves and their families.

Another study (Anser et al., 2020) investigated the dynamic relationship between socio-economic factors and crime rate in a panel of 16 countries, using a time series data from 1990-2014 and found that income inequality and unemployment rate increase crime rate while trade openness supported to decrease crime rate. Umair (2019) attempted to find socioeconomic determinants of crime in Pakistan which used one dependent variable (crimes) and four independent variables (Population growth, net income, inflation and economic growth). Ali and Bibi (2020), in another study analysed how current tax rates, defence expenditures, loans and grants are contributing crime rate to rise in Pakistan. All these factors are increasing economic misery and consequently crime rates.

Another important economic factor that can affects crime rate is the level of education in a country. The level of education generates a "civilization effect" (Usher, 1997). Most of the studies that examine level of education and rate of crime, mainly emphasis how education can polish individual skills and abilities that 
consequently increases the probability to settle in legitimate work force (Khan, Ahmed, Nawaz, and Zaman, 2015; Lochner, 1999; Lochner and Moretti, 2001; Wilson and Herrnstein, 1998). Freeman (1994) suggested to control crime authorities must work in a way where level of education and employment opportunities must process simultaneously. If adequate polices are not put into place for employment generation, the young generation has greater tendency to indulge into criminal activities than the rest of the population. The studies that included a variable to reflect population age effect on crime (Carr-Hill and Stern, 1983; Han, Bandyopadhyay, and Bhattacharya, 2011, 2013a; Machin and Meghir, 2004; Reilly and Witt, 2008; Tarling and Dennis, 2016) has inconsistent findings. This inconsistency largely depends upon the factor like region, wage and income inequalities, poverty, employment opportunities etc.

\section{Methodology}

ARDL approach is used in this paper. It is proposed by Pesaran (1997) and (Pesaran, Shin, and Smith, 1997) and (Pesaran, Shin, and Smith, 2001). ARDL is essentially a combination of two models i.e autoregressive models and distributed lag models. In the said model, a time series model is constructed where the explained variable is the function of its lag values, values of explanatory and lag values those variables. A simple model can be stated as,

$y_{t}=\alpha+\beta_{1} y_{t-1}+\beta_{0} X_{t}+\beta_{1} X_{t-1}+u_{t}$

The generalized form of ARDL can be stated as

$A(L) y_{t}=m+B_{1}(L) x_{i t}+B_{2}(L) x_{2 t}+\cdots \ldots B_{k}(L) x_{k t}+u_{t}$

The model is said to be distributed lag model if $\mathrm{A}(\mathrm{L})=1$.

The ARDL approach to co-integration has several advantages. Bivariate cointegration and multivariate co-integration techniques introduced by Stock and Watson (1993), Johansen (1988) and Søren Johansen (1991); Soren Johansen and Juselius (1990) are best suited for large samples. Although, in small samples (for instance, 30 to 80 values), ARDL approach to co-integration is more suitable. The parameter estimated through ARDL technique are unbiased as it overcomes the issues of serial correlation and endogeneity (Pesaran et al., 2001).

Relative to Engle and Granger's (1987) single equation co-integration approach, the ARDL approach to co-integration has some more advantages. ARDL method to co-integration is applicable even if the explanatory variables are stationary at level $[\mathrm{I}(0)]$ or at first difference $[\mathrm{I}(1)]$ or mutually integrated. However, it's a precondition that explained variable must be stationary at first difference and 
none of the explanatory variable should be hight than the I(2). Furthermore, the ARDL model can facilitate variables that can have different optimal lag lengths. This is another important reason for using ARDL technique over other which is not possible in other typical co-integration approaches. A Dynamic Error Correction Model estimates can be attained through linear transformation of ARDL approach. Such results draw the conclusion for long run estimates. (Banerjee, Dolado, and Mestre, 1998; Sezgin and Yildirim, 2002).

ECM states that change in dependent variable can be decompose into two parts. Firstly, change in repressors and secondly partial correction of the extent to which $y_{t-1}$ is deviated from its equilibrium path. Through the formulation of ECM, reliably the SR dynamics can be defined, along with the long run relationship in a more appropriate way. The coefficient of $\operatorname{ECM}(-1)$ term is considered as the adjustment parameter which specifies the speed of adjustment. The ECM's negative sign displays that it's highly statistically significant which approves the co-integration, and moreover it also determines the long run causal effect. The ECM's negative sign which is considered as the adjustment parameter also approves the model's stability. And the $E C M^{\prime} s(t-1)$ coefficient statistically significant and negative sign shows that the series will be non-explosive and long run equilibrium is attained. For further testation we will apply the "heteroscedasticity", "autocorrelation" and "multicollinearity" test to check the validity of the model. ECM is the most significant method to find the co-integration in the case of inconclusive situation (Banerjee et al., 1998; Kremers, Ericsson, and Dolado, 1992).

In order to examine the existence of short run and long run relationship, the error-correction version of ARDL model in the following way:

$\Delta(Y)=a_{O Y}+\sum_{i=0}^{n} b_{i Y} \Delta(Y)_{t-i}+\sum_{i=0}^{n} c_{i Y} \Delta\left(X_{1}\right)_{t-i}+\sum_{i=0}^{n} d_{i Y} \Delta\left(X_{2}\right)_{t-i}+$ $\sum_{i=0}^{n} e_{i Y} \Delta\left(X_{3}\right)_{t-i}+\sum_{i=0}^{n} f_{i Y} \Delta\left(X_{4}\right)_{t-i}+\sum_{i=0}^{n} g_{i Y} \Delta\left(X_{5}\right)_{t-i}+d 1_{Y} Y_{t-1}+$ $d 2_{X 1} X_{1_{t-1}}+d 3_{X 2} X_{2}{ }_{t-1+} d 4_{X 3} X_{3 t-1}+d 5_{X 4} X_{4 t-1}+d 6_{X 5} X_{5 t-1}$

The coefficients $(\mathrm{a}, \mathrm{b}, \mathrm{c}, \mathrm{d}, \mathrm{e}, \mathrm{f}, \mathrm{g})$ in the equation measures the short run estimates whereas " $d s$ " represent the long run relationships between the variables. There are three step procedures which are utilized by the ARDL model i.e., a) Dynamic analysis b) Long-run relationship c) ECM analysis. In the ARDL approach to co-integration, the first step will be to analyse the relationship between explained and explanatory variable in the long run. This will be attained by the values of F-test statistics on differenced variables components of UECM (Unrestricted Error Correction Mechanism). This helps to find the cumulative significance of the described model. 
The second step of ARDL approach to co-integration ensures the stability of the model through "bound testing procedure". The estimates of long run elasticities are calculated and also it will permit the utilization of "cusum and cusum sum of squares". This procedure will check the consistency and reliability of long run and short run elasticities of the models (Brown, Pusey, Goodwin, and Ottewill, 1975; Pesaran ((a)1997). In the third step, ECM analysis is performed.

\section{Data Sources and Variables}

Time series data for period of 1973-2019 is taken from different economic resources including of Fifty Years of Pakistan Statistics, various issues of Economic Surveys, World Development Indicators. The policy variable (dependent variable) of the model is reported crime. However, different types of crimes as dependent variable are incorporated into the study to perform disaggregated crime analysis. In models, dependent variable is i.e. aggregated (total) crime, crime against person and lastly crime against property. The category of aggregate crime can be described as "sum of reported crimes per one hundred thousand population in a region for given period of time". Crimes can be considered in two forms in disaggregated analysis including crime against person and crimes against property. The first category is type of crimes leads to the injury or death to the individuals. Crimes against person are basically composition of five different categories of crimes including Murder, Attempt to Murder, Hurt, Grievous Hurt Rape, and Kidnapping. Crime against property includes crimes like dacoity, Robbery burglary, cattle theft, and all other thefts. Such crimes lead to deprivation of people from their assets. The explanatory variables including social sector spending, unemployment, income per capita, education measured as secondary enrolment, police strength, income inequalities and poverty are selected in the light of literature review.

\section{Models Specification}

The earlier work of the Gillani et al., (2009), Kustepeli and Onel (2006) and Habibullah and Baharom (2009) have utilized the linear specification of model related to crime. The following three models are constructed by considering three different types of crimes including aggregate crime, crime against property and violence (as discussed before).

\section{Aggregated Crime Model}

The model depicts the effect of certain variables on aggregate crime i.e unemployment (Carr-Hill and Stern, 1983), social sector spending (Anser et al., 2020), education (Khan et al., 2015), population density (Fisher, 1987), per capita 
income (Syed and Ahmed, 2013), GDP growth (Goulas and Zervoyianni, 2013), poverty (Anser et al., 2020), income inequality (Umair, 2019b; Wu and Wu, 2012) and police strength (Chalfin and McCrary, 2017).

$\Delta\left(\ln A g g_{-} C R\right)=a_{o}+\beta_{1} \Delta\left(\ln A g g_{-} C R\right)_{t-1}+\beta_{2} \Delta(\ln S S P)_{t}+$ $\beta_{3} \Delta(\ln S S P)_{t-1}+\beta_{4} \Delta(\ln A U R)_{t}+\beta_{5} \Delta(\ln A U R)_{t-1}+\beta_{6} \Delta(\ln P D)_{t-1}+$ $\beta_{7} \Delta(\ln P S)_{t}+\beta_{8} \Delta(\ln S E)_{t}+\beta_{9} \Delta(\ln S E)_{t-1}+\beta_{10} \Delta(\ln P T)_{t}+$ $\beta_{11} \Delta(\ln P T)_{t-1}+\beta_{12} \Delta(\ln P I)_{t}+\beta_{13} \Delta(\ln P I)_{t-1}+d_{1}\left(\ln \text { Agg }_{-} C R\right)_{t-i}+$ $d_{2}(\ln S S P)_{t}+d_{3}(\ln S S P)_{t-1}+d_{4}(\ln A U R)_{t}+d_{5}(\ln A U R)_{t-1}+$ $d_{6}(\ln P D)_{t-1}+d_{7}(\ln P S)_{t}+d_{8}(\ln S E)_{t}+d_{9}(\ln S E)_{t-1}+d_{10}(\ln P T)_{t}+$ $d_{11}(\ln P T)_{t-1}+d_{12}(\ln P I)_{t}+d_{13}(\ln P I)_{t-1}+u_{t}$

\section{Crime against Property Model}

The following shows factors effecting crime against property, derived from the literature i.e. social sector spending (Ehrlich, 1973a), GDP growth, per-capita income, income inequality, Poverty (Detotto and Otranto, 2012; Han et al., 2013a; Howsen and Jarrell, 1987; Kposowa, Breault, and Harrison, 1995; Syed and Ahmed, 2013), unemployment (Gillanni, Khan, and Gill, 2011; Narayan and Smyth, 2004; J. Phillips and Land, 2012), education (Nguyen, 2019) and population density (Campaniello and Gavrilova, 2018) ${ }^{5}$.

$\Delta\left(\ln\right.$ Pro_CR $\left._{-}\right)=a_{o}^{\prime}+\gamma_{1} \Delta\left(\ln\right.$ Pro_CR $_{t-1}+\gamma_{2} \Delta(\ln S S P)_{t}+$ $\gamma_{3} \Delta(\ln S S P)_{t-1}+\gamma_{4} \Delta(A U R)_{t}+\gamma_{5} \Delta(G W)_{t}+\gamma_{6} \Delta(G W)_{t-1}+\gamma_{7} \Delta(\ln I I)_{t}+$ $\gamma_{8} \Delta(\ln S E)_{t}+\gamma_{9} \Delta(\ln S E)_{t-1}+\gamma_{10} \Delta(\ln P T)_{t}+\gamma_{11} \Delta(\ln P I)_{t}+$ $\gamma_{12} \Delta(\ln P D)_{t}+d^{\prime}{ }_{1}\left(\ln \left(\right.\right.$ Pro_CR $_{t-1}+d_{2}^{\prime}(\ln S S P)_{t}+d^{\prime}{ }_{3}(\ln S S P)_{t-1}+$ $d^{\prime}{ }_{4}(A U R)_{t}+d^{\prime}{ }_{5}(G W)_{t}+d^{\prime}{ }_{6}(G W)_{t-1}+d^{\prime}{ }_{7}(\ln I I)_{t}+d^{\prime}{ }_{8}(\ln S E)_{t}+$ $d^{\prime}{ }_{9}(\ln S E)_{t-1}+d^{\prime}{ }_{10}(\ln P T)_{t}+d^{\prime}{ }_{11}(P I)_{t}+d^{\prime}{ }_{12}(P D)_{t}+v_{t}$

\section{Crime against Person Model}

The equation of crime against person is regressed against, social sector spending, population density, unemployment, income inequality, per-capita income and poverty (Ali and Bibi, 2020; Chisholm and Choe, 2005; Chiu and Madden, 1998b; Forhad and Alam, 2020; Juárez, Urdal, and Vadlamannati, 2020; Khan et al., 2015; Mazorodze, 2020; Narayan and Smyth, 2004; Tripathi, Bugalia, Burdak, and Abbas, 2021; Umair, 2019b).

$$
\begin{aligned}
& \Delta\left(\ln P e r_{-} C R\right)=a^{\prime \prime}{ }_{o}+\delta_{1} \Delta\left(\ln P e r_{-} C R\right)_{t-1}+\delta_{2} \Delta(\ln S S P)_{t}+ \\
& \delta_{3} \Delta(\ln S S P)_{t-1}+\delta_{4} \Delta(A U R)_{t}+\delta_{5} \Delta(P D)_{t}+\delta_{6} \Delta(P D)_{t-1}+\delta_{7} \Delta(\ln I I)_{t}+
\end{aligned}
$$

\footnotetext{
${ }^{5}$ The police strength has more significant effect on crime against person rather than crime against property. The data of court proceedings can depict better results for property crimes.
} 
$\delta_{8} \Delta(\ln P I)_{t}+\delta_{9} \Delta(\ln P T)_{t}+d^{\prime \prime}{ }_{1}\left(\ln P e r_{-} C R\right)_{t-1}+d^{\prime \prime}{ }_{2}(\ln S S P)_{t}+$

$d^{\prime \prime}{ }_{3}(\ln S S P)_{t-1}+d^{\prime \prime}{ }_{4}(A U R)_{t}+d^{\prime \prime}{ }_{5}(P D)_{t}+d^{\prime \prime}{ }_{6}(P D)_{t-1}+d^{\prime \prime}{ }_{7} \Delta(\ln I I)_{t}+$

$\left.d^{\prime \prime}{ }_{8}(P I)_{t}+d^{\prime \prime}{ }_{9}(P T)_{t-1}+e_{t}\right)$

Where,

AggCr stands for aggregate crime

ProCr stands for crime against property

PerCr stands for crime against person

SSP stands for social sector spending

AUR stands for annual unemployment rate

PD stands for population density

PI stands for per capita income in Pak rupee

SE stands for secondary school enrolment

PS stands for police strength

PT stands for poverty

GW stands for GDP growth

II stands for income inequality

\section{Results and Discussion}

Before estimating the short run and long run elasticities for three crime models (aggregated crime, crime against property and crime against person), the overall significance of the model has been test using the bound test (Table 1). The results show that the aggregated crime model as well as the other two models (property crime and crime against person) are significant as all the values are greater than upper bound.

Table 1: Overall Significance Tests of the Crime Models (Bound Test)

\begin{tabular}{llll}
\hline F-Statistics* & & I(0) & I(1) \\
Aggregated Crime Model & 4.02 & 2.467 & 3.614 \\
Crime Against Property & 3.77 & 2.467 & 3.614 \\
Crime Against Person & 3.94 & 2.604 & 3.746 \\
\hline
\end{tabular}

Table 2, 3 and 4 portrays the elasticities for aggregate crime, crime against property and crime against person, respectively. Elasticities represents reaction for the given change in the predictors for the long period of time. The results of the study verified the strong long run relationship between all the variables in all these crime models. Similarly, Table 5, 6 and 7 depicts the short run estimates for the 
said models. The short run causality is attained by performing the Wald test to determine that all the explanatory variables bring out change in the explained variable in short run. However, ECM technique is utilized in short run to compute the elasticities.

Table 2: Estimates for Supply of Aggregate Crime Model in Long Run

\begin{tabular}{|c|c|c|c|}
\hline Independent Variable & Coefficient & Standard Error & t-Ratio \\
\hline Constant & 2.307921 & 3.0124 & 0.76614 \\
\hline $\ln [\operatorname{AggCr}(-1)]$ & 0.585504 & 0.365 & 1.604121 \\
\hline $\ln (\mathrm{SSP})$ & -0.04838 & 0.0214 & -2.26051 \\
\hline $\ln [\operatorname{SSP}(-1)]$ & -0.25648 & 0.1334 & -1.92264 \\
\hline $\ln (\mathrm{AUR})$ & 0.12 & 0.049 & 2.433 \\
\hline $\ln [\operatorname{AUR}(-1)]$ & 2.679 & 1.053 & 2.543 \\
\hline $\ln [P D(-1)]$ & 1.623 & 0.627 & 2.589 \\
\hline $\ln (\mathbf{P S})$ & -1.032 & 0.459 & -2.25 \\
\hline $\ln (\mathrm{SE})$ & -1.2345 & 0.591 & -2.089 \\
\hline $\ln [\operatorname{SE}(-1)]$ & -0.476 & 0.255 & -1.868 \\
\hline $\ln (\mathrm{PT})$ & 0.029 & 0.015 & 1.982 \\
\hline $\ln [\mathrm{PT}(-1)]$ & 0.127 & 0.064 & 1.982 \\
\hline $\ln (\mathbf{P I})$ & -1.31 & 0.584 & -2.244 \\
\hline $\ln [\mathbf{P I}(-1)]$ & -0.478 & 0.213 & -2.244 \\
\hline
\end{tabular}

Diagnostic tests have been applied for Heteroscedasticity, autocorrelation, and stability of parameters $P>0.2 ; R^{2}=0.588$, Normality $(J-B)=1.058(0.679)$.

Table 3: Estimates for Supply of Crime Against Property in Long Run

\begin{tabular}{lcrr}
\hline Independent Variable & Coefficient & Standard Error & t-Ratio \\
Constant & 1.234 & 0.738 & 1.673 \\
Ln[ProCr (-1)] & 0.317 & 0.162 & 1.954 \\
ln(SSP) & -1.134 & 0.398 & -2.848 \\
In [SSP (-1)] & -0.958 & 0.482 & -1.988 \\
AUR & 0.082 & 0.022 & 3.730 \\
GW & -1.192 & 0.521 & -2.286 \\
GW(-1) & 0.934 & 0.427 & 2.187 \\
ln (II) & 0.884 & 0.468 & 1.887 \\
ln(PI) & -0.211 & 0.095 & -2.219 \\
ln PT & 1.795 & 0.816 & 2.201 \\
ln PD & 1.105 & 0.558 & 1.981 \\
ln(SE) & -0.454 & 0.212 & -2.144 \\
ln [SE (-1)] & -0.124 & 0.063 & -1.984 \\
ln PS & -0.052 & 0.021613 & -2.406
\end{tabular}

Diagnostic tests have been applied for Heteroscedasticity, autocorrelation, and stability of parameters $P>0.2 ; R^{2}=0.7$, Normality $(J-B)=1.058(0.499)$.

Table 4: Estimates for Supply of Crime Against Person in Long Run

\begin{tabular}{lccc}
\hline Independent Variable & Coefficient & Standard Error & t-Ratio \\
Constant & -2.1342 & 2.3926 & -0.892 \\
$\ln ($ VioCr$(-1))$ & 0.329 & 0.1711 & 1.923 \\
$\ln (\mathbf{S S P})$ & -1.029 & 0.559 & -1.839 \\
$\ln (\mathbf{S S P}(-1))$ & -1.021 & 0.543 & -1.879 \\
$\ln (\mathbf{A U R})$ & 0.368 & 0.190 & 1.941 \\
$\ln \mathbf{P D}$ & 2.193 & 0.942 & 2.328 \\
$\ln \mathbf{P D}(-1)$ & 0.904 & 0.411 & 2.201 \\
$\ln (\mathbf{I I})$ & 0.722 & 0.363 & 1.991 \\
$\ln (\mathbf{P I})$ & -1.035 & 0.553 & -1.872 \\
$\ln \mathbf{P T}$ & 0.821 & 0.415 & 1.976 \\
\hline Diagnostic tests have been applied for Heteroscedasticity, autocorrelation and stability of parameters $P>0.2 ; R^{2}=0.549$, \\
Normality $(J-B)=1.058$ (0.692).
\end{tabular}


Table 5: Estimates for Supply of Aggregate Crime Model in Short Run

\begin{tabular}{|c|c|c|c|}
\hline Independent Variable & Coefficient & Standard Error & t-Ratio \\
\hline Constant & 1.002 & 3.027 & 0.331 \\
\hline$\Delta \ln [\operatorname{AggCr}(-1)]$ & 0.312 & 0.159 & 1.962 \\
\hline$\Delta \ln (\mathrm{SSP})$ & -0.031 & 0.0150 & -2.06 \\
\hline$\Delta \ln [\operatorname{SSP}(-1)]$ & -0.023 & 0.0108 & -2.129 \\
\hline$\Delta \ln (\mathbf{A U R})$ & 1.686 & 0.8892 & 1.896 \\
\hline$\Delta \ln [\operatorname{AUR}(-1)]$ & 0.686 & 0.3389 & 2.024 \\
\hline$\Delta \ln [P D(-1)]$ & 0.045 & 0.0235 & 1.914 \\
\hline$\Delta \ln (\mathbf{P S})$ & 1.264 & 0.6459 & 1.957 \\
\hline$\Delta \ln (\mathrm{SE})$ & -1.012 & 0.5015 & -2.018 \\
\hline$\Delta \ln [\operatorname{SE}(-1)]$ & -0.156 & 0.0697 & -2.239 \\
\hline$\Delta \ln (\mathbf{P T})$ & 0.042 & 0.0197 & 2.134 \\
\hline$\Delta \ln (\mathbf{P T})$ & 1.033 & 0.5127 & 2.015 \\
\hline $\operatorname{ECM}(-1)$ & -0.374 & 0.1676 & -2.231 \\
\hline
\end{tabular}

Table 6: Estimates for Supply of Crime against Property Model in Short Run.

\begin{tabular}{lccr}
\hline Independent Variable & Coefficient & Standard Error & t-Ratio \\
Constant & 0.03 & 0.0122 & 2.30 \\
$\Delta \ln [$ ProCr $(-1)]$ & 0.14 & 0.0730 & 1.97 \\
$\Delta \ln ($ SSP $)$ & -0.05 & 0.0219 & -2.28 \\
$\Delta \ln [S S P(-1)]$ & -0.03 & 0.0130 & -2.31 \\
$\Delta(A U R)$ & 0.02 & 0.0076 & 1.98 \\
$\Delta G W$ & -1.37 & 0.6031 & -2.28 \\
$\Delta G W(-1)$ & -0.93 & -0.4016 & 2.32 \\
$\Delta \ln (I I)$ & 0.08 & 0.0374 & 2.03 \\
$\Delta \ln (P I)$ & -1.53 & 0.7489 & -2.04 \\
$\Delta \ln P T$ & 0.88 & 0.4156 & 2.11 \\
$E C M 2(-1)$ & -0.42 & 0.2124 & -1.96
\end{tabular}

Diagnostic tests have been applied for Heteroscedasticity, autocorrelation and stability of parameters $P>0.2 ; R^{2}=0.565$, Normality $(J-B)=1.058(0.582)$.

Table 7: Estimates for Supply of Crime Against Person Model in Short Run.

\begin{tabular}{|c|c|c|c|}
\hline Independent Variable & Coefficient & Standard Error & t-Ratio \\
\hline Constant & -0.002 & 0.0019 & -1.03 \\
\hline$\Delta \ln [\operatorname{ProCr}(-1)]$ & 0.197 & 0.2241 & 0.88 \\
\hline$\Delta \ln (S S P)$ & -0.021 & 0.0087 & -2.41 \\
\hline$\Delta \ln [S S P(-1)]$ & -1.923 & -0.7326 & 2.63 \\
\hline$\Delta(\boldsymbol{A U R})$ & 1.743 & 0.7404 & 2.35 \\
\hline$\Delta \boldsymbol{G W}$ & -2.065 & 0.7891 & -2.62 \\
\hline$\Delta G W(-1)$ & -1.097 & 0.4211 & -2.61 \\
\hline$\Delta \ln (I I)$ & 0.847 & -0.4020 & -2.11 \\
\hline$\Delta \ln (P I)$ & 1.352 & -0.5840 & -2.32 \\
\hline$\Delta \ln P T$ & 0.857 & -0.2585 & -3.32 \\
\hline$\underline{\operatorname{ECM3}(-1)}$ & -0.547 & 0.2359 & -2.32 \\
\hline \multicolumn{4}{|c|}{$\begin{array}{l}\text { Diagnostic tests have been applied for Heteroscedasticity, autocorrelation and stability of parameters } P>0.2 ; R^{2}=0.625 \text {, } \\
\text { Normality }(J-B)=1.058(0.413) \text {. }\end{array}$} \\
\hline \multicolumn{4}{|c|}{$\begin{array}{l}\text { The estimates of ARDL confirms the fact that higher unemployment rate } \\
\text { ages the criminal activities. It is evident from results that impact of } \\
\text { loyment is found statistically significant and positive for aggregate crime } \\
\text { long run and short run ( } 2.433 \text { and } 2.966) \text {. For disaggregated analysis, the } \\
\text { of unemployed has been calculated separately for Crime against person and }\end{array}$} \\
\hline
\end{tabular}


Property. The relationship between unemployment and crime against person is positive and significant in both long run and in short run. However, the elasticities of unemployment and crime against property are significant but the relationship is positive in long run but negative in short run. The finding of the study is up to the line of number of studies that state that the existing work ${ }^{6}$ that higher unemployment increase the misery thus increase the illegal behaviour in society. However, some studies have found contrasting results (Andresen, 2012; Narayan and Smyth, 2004; J. Phillips and Land, 2012) that higher rate of unemployment in society lowers the consumption level, thus minimizes the need of the monetary assets through criminal activities to fulfil the desires. Similarly, unemployment rate is likely to have a negative influence on the crime against property as most of the people are sitting idle in their home, thus can look after their possession and control the criminal activities (Syed and Ahmed, 2013). The short run estimated of our study, are also exhibiting the same trend for crime against property in short run.

Social sector spending is found to be negatively and significantly related to all three categories of crime under long run as well as in shortrun. Such spending by the government limits the criminal activities through equalizing and smoothening the society serration (Anser et al., 2020; Ivaschenko, Nivorozhkin, and Nivorozhkin, 2012; Lederman, Loayza, and Menéndez, 2002; Lim and Pickering, 2020; Richmond-Rakerd et al., 2020; Savage, Bennett, and Danner, 2008).

Education and literacy rate is also found to be one of most influencing factors in evoking or inhibiting the criminal activities. However, like unemployment rate, impact of education on crime is ambiguous. The results shows (as depicted in Table 2, Table 3 and Table 4) a negative relation of Secondary enrolment has strong negative impact on crime in long run (as depicted in table 2, Table 3 and Table 4) as well as in short run ((as shown in Table 5, Table 6 and Table 7) that more time spent in educational institutes enhance the discipline and future consciousness (Devi, 2020; Khan et al., 2015; Lance, 2011; Lochner, 1999, 2020; McMillen, Sarmiento-Barbieri, and Singh, 2019; Rakshit and Neog, 2020; Syed and Ahmed, 2013; Usher, 1997; Wassie, Melese, and Eyasu, 2020). Level of education serve as a proxy of opportunity cost of crime. Higher education increases the opportunity cost of crime by decreasing the expected returns from illegal activities. Similarly, higher level of educational attainment increases the probability of getting higher paying jobs. Further, this positive association can also be narrated

\footnotetext{
${ }^{6}$ Altindag, 2012; Burdett et al., 2003; Carmichael and Ward, 2000; Edmark, 2005; Ehrlich, 1973a; Fleisher, 1966; Gillanni, Khan, and Gill, 2011; Han, Bandyopadhyay, and Bhattacharya, 2013b; Juárez, Urdal, and Vadlamannati, 2020; Levitt, 2001; Mazorodze, 2020; Saridakis and Spengler, 2012; Vital, De Souza, and Faciroli, 2020; Wassie, Melese, and Eyasu, 2020)
} 
as higher cost associated with incarceration as educated people have more economic as well as social cost of being found guilty. In oppose, some studies have found that higher educational attainment increases the tendency of white collar crimes such as tax evasion, money laundering (Freeman, 1994; Lochner, 2005; Lochner and Moretti, 2001).

Population density has found a positive related to aggregate crime (as shown in Table 2) and crime against property (as depicted in Table 3). However, this relationship is found to be significant in short run (as shown in Table 4). Rapid increase in the population growth increases the demand for the good and services or in other words more people chasing the few goods. As the population density increases the competition among people over basic needs and economic opportunities thus evoke the crimes. Moreover, higher population growth can make it difficult for the administration to provide all the facilities as well as social security to mass of population leads to increase in illegal activities (Buonanno and Vanin, 2017; Ishak and Bani, 2017; Jendryke and McClure, 2019; Mellgren, Pauwels, and Levander, 2010; Umair, 2019).

The fear of being arrested and punishment exercises a huge impact on illegal activities. As it can be seen from results that police availability ensures through inhibit the indulgence in aggregate crimes. The areas with better police strength both in term of availability increases the cost of illegal activities have better control over the offence occurrence (Devi, 2020; Levitt, 1996, 2017; McMillen et al., 2019; Owens, 2020; L. Phillips and Votey, 1981; Vital, De Souza, and Faciroli, 2020).

In addition to social factors, economics factors can also be regarded as the great contributor to criminal activities. Per capital income has found a negative impact on aggregate crime (Table 2), crime against property (Table 3 ) and crime against person (Table 4). However, this relationship is found significant only in case of crime against property. Higher per capital income can be narrated as more economic opportunities and means to earn livelihood, thus, reduce the crime (Anser et al., 2020; Dutta, Jana, and Kar, 2020; Syed and Ahmed, 2013; Umair, 2019). Thus, raising the per capita income in both absolute and relative term (reducing inequalities) reduce the violent crimes (Astarita, Capuano, and Purificato, 2018; Ehrlich, 1973a ).

Along the same lines, GDP growth have found a negative influence on crime against property and person (as shown in Table 2 and Table 3). Higher GDP growth is associated with more economic opportunities and better means to earn livelihood, thus, reduce crime occurrence. (Umair, 2019). However, these results contradict positive association between crime and GDP found by some studies. As 
per these studies, GDP growth promotes the prosperity so high returns are associated with property crime (Astarita et al., 2018; Detotto and Otranto, 2010; Estrada and Ndoma, 2014; Fisher, 1987; Goulas and Zervoyianni, 2013; Khan et al., 2015).

Poverty act as a corner stone in individual's decision to commit an offence. Poverty is found to have a positive influence on crime against person. Such relationship also holds in short run for aggregate crime (as shown in Table 5).Positive relationship can be narrated as unprivileged people have no means to earn their living expect to indulge in criminal activities to generate income (Anser et al., 2020; Blau and Blau, 1982; Freeman, 1999; Syed and Ahmed, 2013; Vital et al., 2020).

Income Inequalities can be regarded as a key factor in promoting the criminal activities. Income inequalities are positively related to criminal activities (as shown in Table 3 and Table 4). Inequalities have also found to have a significant positive effect on crime against property in short run (as shown in Table 6).Higher income inequalities develop the sense of relative deprivation and evoke the criminal behaviour (Chiu and Madden, 1998; Choe, 2008; Deutsch, Spiegel, and Templeman, 1992; Neumayer, 2005; Wu and Wu, 2012).

In short, all the explanatory variable exhibited the same short run relationship as in long run. However, ECM is performed separately for each model to capture the adjustment mechanism. The ECM's coefficient for aggregated crime (as shown in Table 5) is found to be negative and statistically significant. It depicts that $84 \%$ of the deviation from the long run equilibrium is corrected every year. ECM's coefficient of Crime against property (as shown in Table 6) represents that speed of adjustment to the long run is almost $72 \%$ that is $72 \%$ deviation from the long run is corrected every year.

The coefficient is found to be statistically significant and negative as well. Similarly, ECM's coefficient in the third model, model for crime against person, turn to be negative and statistically significant. The coefficient shows that about $65 \%$ of adjustments are done every year. However, all the finding of the study are up to expectations and highly supported by the previous studies.

\section{Conclusion and Policy Recommendations}

Crime is an endemic for societies and economies, and there is no second thought about it. Crime and violence are the root cause of many socio-economic evil and various socio-economic factors are the reason for high rates of crime all around the world. This paper has used the supply of crime model to determine the 
key factors causing the crime rates, soaring over the period of time in Pakistan. It is also attempted to capture the effect of policing (deterrence) on a limited scale. This paper aimed to estimate the effect of different socio-economic determinants not only on over all criminal activity but also the disaggregated effect on two main categories of crime i.e. crime against person and crime against property.

Three crime supply models were constructed, i.e aggregated crime model, crime against person model (including murder, attempted murder, hurt, grievous hurt, rape, kidnapping) and crime against property model (dacoity, burglary, robbery, cattle theft and miscellaneous theft). All these categories were considered as dependent variable. The supply model of crimes portrayed the effect and relationship of unemployment, population density, social sector spending, education (secondary school enrolment), poverty, GDP Growth, income inequality, and deterrence (police strength) on overall crime rate and upon crime against person and crime against property separately both in long run and short run.

The study leads to various conclusions and policy implications. Unemployment is contributing directly to criminal activity and has long term effects. Unemployment is an economic evil has adverse social and economic effects. Government can combat this issue by introducing different social security programs and can enter into innovative public-private ventures to create more and sustainable job opportunities. Similarly, education can play a positive role in decreases all kinds of illegal activities. Education not only provides serves a medium to attain employment but can also give awareness regarding rights and civic duties. It can help a person to differentiate between right and wrong and create an overall long term positive impact on society. In order to minimize unemployment rate and maximize returns from education, government must spend more on social sector, which is another indicator used in the study and has significant impact on aggregate crime, crime against person and property. There is a need of focused welfare programs, rehabilitation centres for prisoners and vocational training institutes. Similarly, for economic equity eradication of poverty, minimization of income equality and GDP growth is crucial. In certain cases of crime against person and crime against property, the return may not financial but psychological that is due to increasing gap between rich and poor, and lack of fair equal opportunities. The result of the study also supports this argument where poverty and income inequality has shown positive and significant effect on crime rate. Increased per capita income and GDP growth will increase return from legal jobs and activities and will ultimately make individual to trade-off legal work for illegal activities. Population growth is also contributing adversely to crime rate. It does not only reduce job opportunities and increase demand for goods and services 
but also create administrative issues considering per capita police and justice system strength.

Lastly, though not a major indicator has been used for deterrence, but policing has shown a significant impact in controlling crime. This evidence is not enough to draw any sound conclusion but still can indicate a vital role to control increase in crime rate. If more data can be used from justice system, better evaluation can be performed. Increased police strength, timely judgements, investment of forensic sciences can help deter crime in Pakistan.

This paper attempted to profile crime in Pakistan in socio-economic context. Non-availability of classified data and in some cases missing data or nonmaintenance in some provinces create hurdle in developing more profound outcomes. By overcoming this barrier, the research on crime in Pakistan can provide more conclusive results. 


\section{References}

Ali, A., \& Bibi, C. (2020). Public policies, socio-economic environment and crimes in Pakistan: A time series analysis. MPRA Paper, 100216.

Altindag, D. T. (2012). Crime and unemployment: Evidence from Europe. International Review of Law and Economics, 32(1), 145-157.

Andresen, M. A. (2012). Unemployment and crime: A neighborhood level panel data approach. Social Science Research, 41(6), 1615-1628.

Anser, M. K., Yousaf, Z., Nassani, A. A., Alotaibi, S. M., Kabbani, A., \& Zaman, K. (2020). Dynamic linkages between poverty, inequality, crime, and social expenditures in a panel of 16 countries: Two-step GMM estimates. Journal of Economic Structures, 9, 1-25.

Astarita, C., Capuano, C., \& Purificato, F. (2018). The macroeconomic impact of organised crime: A post-Keynesian analysis. Economic Modelling, 68, 514528.

Banerjee, A., Dolado, J., \& Mestre, R. (1998). Error-correction mechanism tests for cointegration in a single-equation framework. Journal of Time Series Analysis, 19(3), 267-283.

Becker, G. S. (1968). Crime and punishment: An economic approach. Journal of Political Economy, 76(2), 169-217.

Blau, J. R., \& Blau, P. M. (1982). The cost of inequality: Metropolitan structure and violent crime. American Sociological Review, 47(1), 114-129.

Brown, J. C., Pusey, P. N., Goodwin, J. W., \& Ottewill, R. H. (1975). Light scattering study of dynamic and time-averaged correlations in dispersions of charged particles. Journal of Physics A: Mathematical and General, 8(5), 664.

Buonanno, P., \& Vanin, P. (2017). Social closure, surnames and crime. Journal of Economic Behavior and Organization, 137, 160-175.

Burdett, K., Lagos, R., \& Wright, R. (2003). Crime, inequality, and unemployment. American Economic Review, 93(5), 1764-1777.

Carmichael, F., \& Ward, R. (2000). Youth unemployment and crime in the English regions and Wales. Applied Economics, 32(5), 559-571.

Carr-Hill, R. A., \& Stern, N. H. (1983). Unemployment and crime: A comment. Journal of Social Policy, 12(3), 387-392.

Chiricos, T. G. (1987). Rates of crime and unemployment: An analysis of aggregate 
research evidence. Social Problems, 34(2), 187-212.

Chisholm, J., \& Choe, C. (2005). Income variables and the measures of gains from crime. Oxford Economic Papers, 57(1), 112-119.

Chiu, W. H., \& Madden, P. (1998). Burglary and income inequality. Journal of Public Economics, 69(1), 123-141.

Choe, J. (2008). Income inequality and crime in the United States. Economics Letters, 101(1), 31-33.

Detotto, C., \& Otranto, E. (2010). Does crime affect economic growth? Kyklos, 63(3), 330-345.

Deutsch, J., Spiegel, U., \& Templeman, J. (1992). Crime and income inequality: An economic approach. Atlantic Economic Journal, 20(4), 46-54.

Devi, Tanaya. (2020). Essays in the Economics of Crime and Education (doctoral dissertation). Graduate School of Arts \& Sciences, Harvard University.

Dutta, N., Jana, D., \& Kar, S. (2020). Does state-level per capita income affect juvenile delinquency? An empirical analysis for Indian states. Economic Modelling, 87, 109-120.

Edmark, K. (2005). Unemployment and crime: Is there a connection? Scandinavian Journal of Economics, 107(2), 353-373.

Ehrlich, I. (1973). Participation in illegitimate activities: A theoretical and empirical investigation. Journal of Political Economy, 81(3), 521-565.

Ehrlich, I. (1973). The deterrent effect of capital punishment: A question of life and death. National Bureau of Economic Research, w0018.

Estrada, M. A. R., \& Ndoma, I. (2014). How crime affects economic performance: The case of Guatemala. Journal of Policy Modeling, 36(5), 867-882.

Fisher, S. (1987). Economic development and crime: The two may be associated as an adaptation to industrialism in social revolution. American Journal of Economics and Sociology, 46(1), 17-34.

Fisher, T. (2015). The Oxford Handbook of Criminal Law. Available at: https://doi.org/10.1093/oxfordhb/9780199673599.001.0001

Fleisher, B. M. (1966). The effect of income on delinquency. The American Economic Review, 56(2), 118-137.

Forst, B. (1993). The Socio Economics of Crime and Justice. ME Sharpe: United State 
America.

Freeman, R. B. (1994). Crime and the job market. National Bureau of Economic Research, No. w4910.

Freeman, R. B. (1999). The economics of crime. Handbook of Labour Economics, 3, 3529-3571.

Gillanni, S. Y. M., Khan, R. E. A., \& Gill, A. R. (2011). Unemployment and property crimes in Pakistan. Asian Economic and Financial Review, 1(3), 124-133.

Goulas, E., \& Zervoyianni, A. (2013). Economic growth and crime: Does uncertainty matter? Applied Economics Letters, 20(5), 420-427.

Han, L., Bandyopadhyay, S., \& Bhattacharya, S. (2013b). Determinants of violent and property crimes in England and Wales: A panel data analysis. Applied Economics, 45(34), 4820-4830.

Hellman, D. A., \& Alper, N. (2000). Economics of Crime: Theory and Practice $\left(6^{\text {th }}\right.$ Edition). Pearson.

Higgins, G. E., Gabbidon, S. L., \& Martin, F. (2010). The role of race/ethnicity and race relations on public opinion related to the immigration and crime link. Journal of Criminal Justice, 38(1), 51-56.

Imrohoroglu, A., Merlo, A., \& Rupert, P. (2001). What accounts for the decline in crime?. USC Finance \& Business Econ, Working Paper, 01-12.

Ishak, S., \& Bani, Y. (2017). Determinants of crime in Malaysia: Evidence from developed states. International Journal of Economics \& Management, 11, 607-622.

Ivaschenko, O., Nivorozhkin, A., \& Nivorozhkin, E. (2012). The role of economic crisis and social spending in explaining crime in Russia: Regional panel data analysis. Eastern European Economics, 50(4), 21-41.

Jendryke, M., \& McClure, S. C. (2019). Mapping crime hate crimes and hate groups in the USA: A spatial analysis with gridded data. Applied Geography, 111, 110.

Johansen, Søren. (1988). Statistical analysis of cointegration vectors. Journal of Economic Dynamics and Control, 12(3), 231-254.

Johansen, Søren. (1991). Estimation and hypothesis testing of cointegration vectors in gaussian vector autoregressive models. Econometrica: Journal of the Econometric Society, 59(6), 1551-1580. 
Johansen, Soren, \& Juselius, K. (1990). Maximum likelihood estimation and inference on cointegration with appucations to the demand for money. Oxford Bulletin of Economics and Statistics, 52(2), 169-210.

Khan, N., Ahmed, J., Nawaz, M., \& Zaman, K. (2015). The Socio economic determinants of crime in Pakistan: New evidence on an old debate. Arab Economic and Business Journal, 10(2), 73-81.

Kremers, J. J. M., Ericsson, N. R., \& Dolado, J. J. (1992). The power of cointegration tests. Oxford Bulletin of Economics and Statistics, 54(3), 325-348.

Lance, L. (2011). Nonproduction benefits of education: Crime, health, and good citizenship. Handbook of the Economics of Education, 4, 183-282.

Lederman, D., Loayza, N., \& Menéndez, A. M. (2002). Violent crime: Does social capital matter? Economic Development and Cultural Change, 50(3), 509-539.

Levitt, S. D. (1996). The effect of prison population size on crime rates: Evidence from prison overcrowding litigation. The Quarterly Journal of Economics, 111(2), 319-351.

Levitt, S. D. (2001). Alternative strategies for identifying the link between unemployment and crime. Journal of Quantitative Criminology, 17(4), 377390.

Levitt, S. D. (2017). Juvenile crime and punishment. Juvenile Crime and Punishment, 106(6), 1156-1185.

Lim, K. Y., \& Pickering, R. (2020). Crime heterogeneity and welfare spending: theory and empirical evidence based on the universal credit system. Nottingham Business School Discussion Paper, 2020/04.

List, J., \& Uhlig, H. (2017). The past, present, and future of economics: A celebration of the 125-year anniversary of the JPE and of chicago economics. Journal of Political Economy, 125(6), 1723-1727.

Lochner, L. (1999). Education, work, and crime: Theory and evidence. Rochester Center for Economic Research Working Paper, 465.

Lochner, L. (2020). Education and Crime. In The Economics of Education, 109-117, Academic Press.

Machin, S., \& Meghir, C. (2004). Crime and economic incentives. Journal of Human Resources, 39(4), 958-979.

Mazorodze, B. T. (2020). Youth unemployment and murder crimes in KwaZulu- 
Natal, South Africa. Cogent Economics \& Finance, 8(1), 1-17.

McMillen, D., Sarmiento, B. I., \& Singh, R. (2019). Do more eyes on the street reduce Crime? Evidence from Chicago's safe passage program. Journal of Urban Economics, 110, 1-25.

Narayan, P. K., \& Smyth, R. (2004). Crime rates, male youth unemployment and real income in Australia: Evidence from granger causality tests. Applied Economics, 36(18), 2079-2095.

Neumayer, E. (2005). Inequality and violent crime: Evidence from data on robbery and violent theft. Journal of Peace Research, 42(1), 101-112.

Owens, E. (2020). The Economics of Policing. Handbook of Labor, Human Resources and Population Economics, 1-30.

Pesaran, M. H. (1997). The role of economic theory in modelling the long run. The Economic Journal, 107(440), 178-191.

Pesaran, M. H., Shin, Y., \& Smith, R. J. (2001). Bounds testing approaches to the analysis of level relationships. Journal of Applied Econometrics, 16(3), 289326.

Pesaran, M. H., Shin, Y., \& Smith, R. P. (1997). Pooled estimation of long-run relationships in dynamic heterogeneous panels. Journal of the American Statistical Association, 94(446), 621-634.

Phillips, J., \& Land, K. C. (2012). The link between unemployment and crime rate fluctuations: An analysis at the county, state, and national levels. Social Science Research, 41(3), 681-694.

Phillips, L., \& Votey, H. L. (1981). The Economics of Crime Control. Sage Publications Beverly Hills, CA.

Pratt, T. C., \& Cullen, F. T. (2005). Assessing macro-level predictors and theories of crime: A meta-analysis. Crime and Justice, 32, 373-450.

Rakshit, B., \& Neog, Y. (2020). Does higher educational attainment imply less crime? Evidence from the Indian states. Journal of Economic Studies, 48(1), 133-165.

Reilly, B., \& Witt, R. (2008). Domestic burglaries and the real price of audio-visual goods: Some time series evidence for Britain. Economics Letters, 100(1), 96100.

Richmond-Rakerd, L. S., D’Souza, S., Andersen, S. H., Hogan, S., Houts, R. M., Poulton, R., \& Moffitt, T. E. (2020). Clustering of health, crime and social 
welfare inequality in 4 million citizens from two nations. Nature Human Behaviour, 4(3), 255-264.

Saridakis, G., \& Spengler, H. (2012). Crime, deterrence and unemployment in Greece: A panel data approach. Social Science Journal, 49(2), 167-174.

Savage, J., Bennett, R. R., \& Danner, M. (2008). Economic assistance and crime: A cross-national investigation. European Journal of Criminology, 5(2), 217238.

Sezgin, S., \& Yildirim, J. (2002). The demand for Turkish defence expenditure. Defence and Peace Economics, 13(2), 121-128.

Stock, J. H., \& Watson, M. W. (1993). A simple estimator of cointegrating vectors in higher order integrated systems. Econometrica: Journal of the Econometric Society, 783-820.

Syed, S. H., \& Ahmed, E. (2013). Poverty, inequality, political instability and property crimes in Pakistan: A time series analysis. Asian Journal of Law and Economics, 4(1-2), 1-28.

Tarling, R., \& Dennis, R. (2016). Socio economic determinants of crime rates: Modelling local area police recorded crime. The Howard Journal of Crime and Justice, 55(1-2), 207-225.

Umair, M. (2019). The socioeconomic determinants of crime in Pakistan. Budapest International Research and Critics Institute Journal: Humanities and Social Sciences, 2(3), 1-6.

Usher, D. (1997). Education as a deterrent to crime. Canadian Journal of Economics, 367-384.

Vital, T., De Souza, D. M., \& Faciroli, J. (2020). Unemployment, poverty and police performance: An ARDL analysis of crime in SÃ£ o Paulo. Economics Bulletin, 40(1), 128-139.

Wassie, N., Melese, B., \& Eyasu, N. (2020). Socioeconomic determinants of property crime offending in Ethiopia: Convicted offenders in focus. Journal of Financial Crime. Available at: https://doi.org/10.1108/JFC-11-2019-0145

Wilson, J. Q., \& Herrnstein, R. J. (1998). Crime Human Nature: The Definitive Study of the Causes of Crime. Simon and Schuster: United States.

$\mathrm{Wu}, \mathrm{D} .$, \& Wu, Z. (2012). Crime, inequality and unemployment in England and Wales. Applied Economics, 44(29), 3765-3775. 